\title{
How does Cariniana estrellensis respond to different irradiance levels?
}

\author{
Flávia Carolina Santos Portela ${ }^{1}$ Bernardo Pretti Becacici Macieira ${ }^{1}$. \\ Leonardo Valandro Zanetti ${ }^{1}$ - Vinícius Novo Gama ${ }^{1} \cdot$ Diolina Moura Silva ${ }^{1}$. \\ Camilla Rozindo Dias Milanez ${ }^{1}$ - Geraldo Rogério Faustini Cuzzuol ${ }^{1}$
}

Received: 1 February 2017 / Accepted: 13 April 2017/Published online: 23 January 2018

(C) The Author(s) 2018. This article is an open access publication

\begin{abstract}
Based on reports that variables related to photosynthesis (net assimilatory ratio and chloroplast pigments) are more plastic than the morphological and biochemical variables in a climax tropical species, Cariniana estrellensis, under contrasting irradiance, we hypothesised that plasticity of gas exchange variables is higher in relation to growth, biochemical and anatomical variables. Plants that were 14 months old were subjected to 200 up to $2000 \mu \mathrm{mol} \mathrm{m} \mathrm{m}^{-2} \mathrm{~s}^{-1}$ of photo synthetically active radiation (PAR) for 140 days. Growth increased up to $1400 \mu \mathrm{mol} \mathrm{m}{ }^{-2} \mathrm{~s}^{-1}$ PAR and then decreased at $2000 \mu \mathrm{mol} \mathrm{m}{ }^{-2} \mathrm{~s}^{-1}$ PAR (full sunlight). This was related to the rate of photosynthesis $(A)$ which showed the same tendency as photosystem II performance index $\left(\mathrm{PI}_{\mathrm{ABS}}\right)$. The greater thickness of the secondary xylem at $1400 \mu \mathrm{mol} \mathrm{m}{ }^{-2} \mathrm{~s}^{-1}$ PAR indicated a higher water conductance capacity. The decrease in specific leaf area, elongation of mesophyll cells, and increase in stomatal density observed at higher irradiances were associated with
\end{abstract}

Project Funding: This work was supported by the National Plan for the Support and Development of Botany-Coordination for the Improvement of Higher Education Personnel (PNADB-CAPES) (Process 1147/2010), the National Council for Scientific and Technological Development (CNPq) for the Science Productivity Scholarship (Process 305447/2012-2).

The online version is available at http://www.springerlink.com

Corresponding editor: $\mathrm{Hu}$ Yanbo.

Geraldo Rogério Faustini Cuzzuol

gcuzzuol@gmail.com

1 Department of Biological Sciences, Federal University of Espírito Santo, Vitória, Espírito Santo CEP 29075-910, Brazil higher leaf fructose and sucrose concentrations. We concluded that the better growth in partial shade was due to higher photosynthetic capacity. On the other hand, photosynthesis was inhibited equally in full sun and deep shade. The high adjustment capacity of $C$. estrellensis to wide amplitudes of irradiance was provided by greater plasticity of gas exchange variables in relation to growth, anatomical, and biochemical variables.

Keywords Anatomy · Ecophysiology · Gas exchange · Phenotypic plasticity $\cdot$ Soluble carbohydrates

\section{Introduction}

Non-pioneer or shade tolerant species develop morphological, anatomical and physiological adjustments under deep shade (shade tolerance syndrome) that are characterised by a higher investment in leaf area. This is reflected in an increased leaf area ratio (LAR) and specific leaf area (SLA), and a decreased blade thickness because of the reduced elongation of mesophyll cells (Lambers et al. 2008). These adjustments improve the capture of low light in highly shaded environments, where certain tropical tree species tend to have lower relative growth rates (RGR) (Souza and Válio 2003), higher chlorophyll concentrations (Gonçalves et al. 2005), higher photosynthetic activity (Silvestrini et al. 2007), and lower concentrations of soluble carbohydrates (Marenco et al. 2001; Mengarda et al. 2012).

Shade tolerant tropical species can survive in full sunlight (Souza and Válio 2003) or under intermediate shading of around $50 \%$ of photosynthetic photon flux (Gonçalves et al. 2005; Mengarda et al. 2009). Independent of the functional class, Frigeri (2007) observed that certain 
climax (shade tolerant) and pioneer (shade intolerant) species from a Brazilian semi- deciduous tropical forest grew better under intermediate shade. The author concluded that shade species tolerate direct light and show high survival with limited growth. This was attributed to the high phenotypic plasticity of the climax species, which is not in accordance with the established concept that shade or understory species have low plasticity compared with pioneer species (Valladares et al. 2000; Hanba et al. 2002; Oguchi et al. 2005). Similar results were also reported by Mengarda et al. (2009) for young plants of Caesalpinia echinata Lam., a climax species of Brazil's Atlantic Forest (Budowski 1965), but showed better photosynthetic performance and growth in 50\% of PAR photosynthetically active radiation (Mengarda et al. 2009). Under full sunlight, Mengarda et al. (2009) observed that C. echinata plants tolerated high irradiance, although they had decreased photosynthetic rates $(A)$ and photosystem II photochemical efficiency $\left(\mathrm{F}_{\mathrm{V}} / \mathrm{F}_{\mathrm{M}}\right)$. The capacity of $C$. echinata to tolerate high irradiance was associated with increased soluble carbohydrate concentrations, increased length of mesophyll cells, higher water contents, and improved recovery of the photochemical capacity of plants transferred to full sunlight (Mengarda et al. 2012).

Shade tolerant or climax species from Brazilian tropical forests grew better under light near 50\% of direct irradiance (Gonçalves et al. 2005; Frigeri 2007; Mengarda et al. 2009). The variables related to photosynthesis (net assimilatory ratio-NAR and chloroplastidics pigments) are more plastic than the morphology and biochemistry in non-pioneer tropical trees Cariniana estrellensis (Raddi) Kuntze, Cedrela odorata L., and Manilkara salzmannii (A. DC.) H. J. Lam under contrasting irradiance (Gaburro et al. 2014), we hypothesised that the better growth of shade tolerant species under partial shade and high capacity to adjust to wide amplitudes of irradiance (full sun to deep shade) to be due to its greater plasticity of gas exchange variables in relation to growth and biochemical variables (leaf soluble carbohydrates-glucose, fructose and sucrose). To test this hypothesis, we used as a model the climax species, $C$. estrellensis (Lecythidaceae) (Swaine and Whitmore 1988), which has a Neotropical distribution. It is highly representative of the semi- deciduous rainforests of Espírito Santo State, Brazil where this study was conducted. $C$. estrellensis is endangered because of its intensive exploitation by the wood industry, and it is fundamental for ecological reforestation. The aim of this study was to identify the phenotypic variables (growth, photosynthesis, biochemical and anatomy) with greater plasticity in $C$. estrellensis.

\section{Materials and methods}

\section{Experimental design}

Cariniana estrellensis seeds were collected in the semideciduous evergreen forest (Engel 2001) at the Vale Nature Reserve located in Sooretama city, Espírito Santo State $\left(19^{\circ} 11^{\prime} 30^{\prime \prime} \mathrm{S}\right.$ and $40^{\circ} 05^{\prime} 46^{\prime \prime} \mathrm{W}, 58 \mathrm{~m}$ altitude) August 2011. The understory PAR was measured between 9:00 a.m. and 10:00 a.m. at the base of 10 trees from which the seeds were collected. PAR was measured using a spectroradiometer (Spectrum Technologies, Inc., Illinois, USA) with three repetitions at $1 \mathrm{~min}$ intervals. The sensor was placed $1 \mathrm{~m}$ above the ground and under the canopy of each tree. These trees had an average distance of 40-100 m between them. An average PAR value of $200 \pm 80 \mu \mathrm{mol} \mathrm{m}{ }^{-2} \mathrm{~s}^{-1}$ was found for the low rainfall season (winter). The seeds were sown in trays under shade screen in wood frame boxes containing washed sand $(1.5 \mathrm{~m}$ height $\times 1.5 \mathrm{~m}$ wide $\times 1.5 \mathrm{~m}$ deep) with $200 \mu \mathrm{mol} \mathrm{m}^{-2} \mathrm{~s}^{-1}$ PAR and environmental condition $\left(28 \pm 2{ }^{\circ} \mathrm{C}\right.$ temperature, $75 \pm 8 \%$ relative humidity, and $11 \pm 1 \mathrm{~h}$ natural photoperiod). PAR was measured using a spectroradiometer (Spectrum Technologies, Inc., Illinois, USA) at 9:00 a.m. on a sunny day. The germination was low at approximately 40\%. Following germination, the seedlings were transferred into $8 \mathrm{~L}$ polyethylene pots containing compost, sand, and clay (1:1:1), and kept under the same conditions as germination. After 14 months of growth, 20 homogeneous plants with height $20 \pm 3 \mathrm{~cm}$ and $8 \pm 2$ leaves were transferred to another shade screen boxes with $1000 \pm 52$, $1400 \pm 89$ and $2000 \pm 102$ (full sunlight) $\mu \mathrm{mol} \mathrm{m} \mathrm{m}^{-2} \mathrm{~s}^{-1}$ PAR, four treatments in total including $200 \mu \mathrm{mol} \mathrm{m}{ }^{-2} \mathrm{~s}^{-1}$ PAR. The boxes were exposed to environmental variables such as rain, wind, temperature and radiance. Environmental conditions inside the boxes were $28 \pm 2{ }^{\circ} \mathrm{C}$ temperature, $75 \pm 8 \%$ relative humidity, and $11 \pm 1 \mathrm{~h}$ natural photoperiod at the beginning of the experiment. Treatments started in January (summer) and continued until April (autumn) 2012, completing 90 days when the greatest differences in heights occurred. The plants were watered weekly to field capacity to prevent water deficits. At the beginning and at the end of the experiment, growth variables (photosynthesis, biochemical and anatomical) were measured. Only an analysis was conducted due to limited number of plants and physical space. Of the 20 plants, eight were used for growth measurements and six for anatomy, biochemistry and photosynthetic analysis, and leaving six plants as spares. The data collections for photosynthesis, and biochemical and anatomical variables were carried out a day before the growth measures due to inability to carry out all measures on the same day. 


\section{Growth analysis}

Growth measurements were taken at 0 and 90 days. Stem length and diameter were measured using a digital pachymeter. Root, stem and leaf dry mass were measured following drying in an oven at $60{ }^{\circ} \mathrm{C}$ until a constant mass was obtained, and the leaf area was measured using a scanner (Area Meter, LI-COR 3100, Nebraska, USA). These data were used to calculate the specific leaf area $(\mathrm{SLA}=\mathrm{A} / \mathrm{LDM})$, unit leaf area $(\mathrm{ULA}=\mathrm{A} / \mathrm{LN})$, relative growth rate $\left(\mathrm{RGR}=\left(\mathrm{LnM}_{2}-\mathrm{LnM}_{1}\right) /\left(\mathrm{t}_{2}-\mathrm{t}_{1}\right)\right)$, net assimilation rate $\left(\mathrm{NAR}=\left[\left(\mathrm{LnA}_{2}-\mathrm{LnA}_{1}\right) /\left(\mathrm{A}_{2}-\mathrm{A}_{1}\right)\right] \times\right.$ $\left.\left[\left(M_{2}-M_{1}\right) /\left(t_{2}-t_{1}\right)\right]\right)$, leaf area ratio $(\operatorname{LAR}=A / T D M)$, root: shoot ratio (R:S), and biomass allocation. Biomass allocation was calculated as the ratio of the dry mass of each plant component divided by the total dry mass (Lambers and Poorter 1992), where $\mathbf{M}_{1}=$ initial mass, $\mathrm{M}_{2}=$ final mass, $\mathrm{t}_{1}=$ initial time, $\mathrm{t}_{2}=$ final time, $\mathrm{Ln}=$ natural $\mathrm{Log}, \mathrm{LDM}=$ leaf dry mass, $\mathrm{SDM}=$ stem dry mass, $\mathrm{RDM}=$ root dry mass, TDM = total dry mass, $\mathrm{A}=$ leaf area, and $\mathrm{LN}=$ number of leaves.

\section{Pigments and photosynthesis}

Chlorophyll $a(\mathrm{Chl} a)$ and $b(\mathrm{Chl} b)$ and carotenoids (Carot) were extracted in $10 \mathrm{~mL}$ dimethyl sulfoxide (DMSO) using $20 \mathrm{mg}$ fresh mass of fully expanded leaves $\left(40 \mathrm{~cm}^{2} \pm 2\right.$ unitary) located at the third node of six plants. The samples were placed into test tubes with screw caps wrapped in aluminium foil and heated in a water bath at $60{ }^{\circ} \mathrm{C}$ for $4 \mathrm{~h}$. The absorbance was measured at 480, 645 and $663 \mathrm{~nm}$ using a spectrophotometer (Genesys 10S UV-Vis, Thermo Fisher Scientific, Waltham, USA). Chl $a$ and $b$ and Carot concentrations were calculated using Lichtenthaler and Welburn (1983) equations. The results were used to calculate Chl $a: b$ and $\mathrm{Ch}_{\text {Total }}$ : Carot ratios. Gas exchange was measured at 8:00 a.m. on the same leaves used for extraction of the photosynthetic pigments with a portable infrared gas analyser (IRGA) (LI-6200, LI-COR Inc., Lincoln, USA) in a closed system at $380 \mathrm{ppm} \mathrm{CO}_{2}$ concentration and $28{ }^{\circ} \mathrm{C}$. An artificial light source was used with approximately $1500 \mu \mathrm{mol} \mathrm{m} \mathrm{m}^{-2} \mathrm{~s}^{-1}$ light intensity (Vieira et al. 2011). Carbon photosynthetic assimilation ( $A$, $\left.\mu \mathrm{mol} \mathrm{CO}_{2} \mathrm{~m}^{-2} \mathrm{~s}^{-1}\right)$, stomatal conductance $\left(g s, \mathrm{~mol} \mathrm{H} \mathrm{H}_{2}\right.$ $\mathrm{O} \mathrm{m}^{-2} \mathrm{~s}^{-1}$ ), transpiration $\left(E\right.$, mmol $\mathrm{H}_{2} \mathrm{O} \mathrm{m}^{-2} \mathrm{~s}^{-1}$ ), water use efficiency $\left(A / E, \mu \mathrm{mol} \mathrm{CO}_{2} \cdot \mathrm{mmol}^{-2} \mathrm{H}_{2} \mathrm{O}\right)$, and carboxylation efficiency $\left(\mathrm{A} / \mathrm{Ci}\right.$, mol air $\left.\mathrm{m}^{-2} \mathrm{~s}^{-1}\right)$ were determined.

\section{Chlorophyll $\boldsymbol{a}$ fluorescence}

Chl $a$ fluorescence emission kinetics were measured on the same leaves used for the photosynthesis and pigment measurements with a Handy PEA portable fluorimeter (Plant Efficiency Analyzer, Hansatech, King's Lynn, UK). Measurements were performed at 8:00 a.m. on the darkadapted leaves for $30 \mathrm{~min}$. Immediately following, the leaves were exposed to a $3000 \mu \mathrm{mol} \mathrm{m}^{-2} \mathrm{~s}^{-1}$ red light saturating pulse. The OJIP fluorescence transients obtained for each treatment were analysed according to the JIP test (Strasser et al. 2004) using the software Biolyzer (Bioenergetics Laboratory, University of Geneva, Switzerland). The following parameters were analysed: (1) energy absorption per active photosystem II (PSII) reaction centre (RC) (ABS/RC), which can also represent the apparent size of the PSII antenna; (2) energy dissipation per active PSII reaction centre $\left(\mathrm{DI}_{0} / \mathrm{RC}\right)$; and, (3) efficiency with which a trapped exciton can move an electron into the electron transport chain further than quinone $\mathrm{A}\left(\mathrm{Q}_{\mathrm{A}}\right)$ at time zero $\left[\mathrm{ET}_{0} / \mathrm{TR}_{0}(\mathrm{time}=0)\right]$. The following energy conservation and photochemical efficiency parameters were also analysed: (1) net rate of active PSII reaction centres (RC/ABS); (2) maximum PSII quantum yield or the maximum quantum yield of the primary photochemistry $\left(\Phi \mathrm{P}_{0}=\mathrm{F}_{\mathrm{V}} / \mathrm{F}_{\mathrm{M}}\right)$; and, (3) performance index which is a reflection of the efficiency of light energy absorption, the efficiency of $\mathrm{Q}_{\mathrm{A}}^{-}$ reduction, and the energy conversion to electron transport $\left(\mathrm{PI}_{\mathrm{ABS}}\right)$ (Strasser et al. 2010; Xiang et al. 2013).

\section{Soluble carbohydrates}

Soluble carbohydrates were extracted from a $1 \mathrm{~g}$ of fresh mass of the same leaves used for the $\mathrm{Chl} a$ fluorescence and photosynthesis measurements. The samples were boiled in $10 \mathrm{~mL}$ of $80 \%$ ethanol for $3 \mathrm{~min}$ to inactivate the enzymes, ground and soluble carbohydrates were extracted in a water bath at $80^{\circ} \mathrm{C}$ for $15 \mathrm{~min}$. The extract was centrifuged at $4500 \mathrm{~g}$ for $15 \mathrm{~min}$, the supernatant collected, and the procedure repeated twice. The three resultant supernatants were pooled and concentrated in a rotary evaporator (QUIMIS $^{\circledR}$, Q344B1, Diadema, Brazil) at $35 \mathrm{rpm}$ and $40{ }^{\circ} \mathrm{C}$. The total soluble carbohydrate (TSC) concentration was determined according to the phenol-sulphuric acid method (Dubois et al. 1956); the free and combined fructose content determined using acid hydrolysis and anthrone (Jermyn 1956); and the sucrose concentration determined according to the reducing carbohydrates degradation method using potassium hydroxide $(\mathrm{KOH}, 5.4 \mathrm{~N})$ (Riazi et al. 1985). A calibration curve was built using fructose standards with 0 to $50 \mu \mathrm{g}$ of fructose. The absorbances were measured at $\lambda=620 \mathrm{~nm}$ using a spectrophotometer, and the free glucose estimated using the BioSystem enzymatic method. The reaction involved glucose oxidase and peroxidase on glucose and aminoantipyrine + phenol, respectively, which produced quinoneimine. A $10 \mu \mathrm{g}$ 
glucose/urea/creatine solution was used as the standard, and the absorbances were measured at $500 \mathrm{~nm}$.

\section{Leaf and stem anatomy}

Fully expanded leaves at the fourth node and stem segments $40 \mathrm{~cm}$ above-ground were collected from the same six plants used for photosynthesis and biochemistry analyzes. The samples were fixed in FAA 70 (formaldehyde, acetic acid, and $70 \%$ ethanol) for $48 \mathrm{~h}$ (Johansen 1940) and stored in $70 \%$ ethanol. Cross sections from the stem and middle third of the leaf blade were obtained manually using steel razors. The sections were stained with safranin-astra blue (Bukatsch 1972 adapted by Kraus and Arduim 1997), and histological slides prepared with glycerin: water $(1: 1)$ and sealed with colourless enamel. The quantitative leaf anatomical characteristics included: thickness of the leaf blade, adaxial and abaxial epidermis, and palisade and spongy parenchyma, and stomatal density $\left(\mathrm{n}^{\mathrm{o}} \mathrm{mm}^{-2}\right)$. Measurements of the tissues were from transverse sections. Stomatal density was determined by imprinting the abaxial leaf surface in glass slides using a cyanoacrylate ester adhesive (Super Bonder ${ }^{\circledR}$ ). The quantitative stem anatomical characteristics included the following: thickness of the periderm; secondary phloem; cambial zone (radial rows of fusiform and ray initials, including phloem and xylem mother cells according to Marcati et al. 2008); secondary xylem; and vessel element diameter, length and density. Measurements of the stem tissues were taken from transverse sections. The length was determined in dissociated cells according to Franklin's method (1945), modified by Kraus and Arduim 1997). Dissociated cells were stained with aqueous $1 \%$ safranin (Sass 1958), and semi-permanent slides mounted in glycerin: water (1:1). Observations and image capture were recorded with a photomicroscope (Nikon, 50i, Tokyo, Japan) and measurements with a TSView v.6.1.3.2 (Tucsen Imaging Technology Co. Limited, China) image analyser.

\section{Phenotypic plasticity}

This analysis was calculated for all variables (growth, photosynthesis, biochemistry and anatomical). Plasticity is the variation of the species phenotype that results from the plant's adaptive responses to different irradiance levels. The phenotypic plasticity index (PI), which varies between 0 and 1 , was calculated as the difference between the highest and lowest average values of the different treatments divided by the highest average value (Valladares et al. 2000, 2005). Higher PI values that are closer to 1 indicate that the variable is more plastic (Valladares et al. 2005).

\section{Statistical analyses}

The data were subjected to one-way ANOVA analyses and the means compared by the Tukey test at $5 \%$ probability. For all statistical analyses, a normality test was applied using the software ASSISTAT (version 7.7 beta). The Chla fluorescence parameters were normalised relative to the variable relative fluorescence $\left[\mathrm{Vt}=\left(\mathrm{F}_{\mathrm{t}}-\mathrm{F}_{\mathrm{M}}\right)\right.$ / $\left.\left(F_{M}-F_{0}\right)\right]$, where $F_{t}=$ fluorescence in the variable time or transient fluorescence, $F_{0}=$ initial fluorescence, and $\mathrm{F}_{\mathrm{M}}=$ maximal fluorescence (Yusuf et al. 2010).

\section{Results}

\section{Growth analysis}

Stem heights and diameters (Fig. 1) were larger under $1400 \mu \mathrm{mol} \mathrm{m} \mathrm{s}^{-2}$ PAR (partial shading) and decreased with $2000 \mu \mathrm{mol} \mathrm{m}{ }^{-2} \mathrm{~s}^{-1}$ PAR (full sunlight). Heights were smaller in the lowest and highest irradiances and similar. The number of leaves and SLM were higher at the highest irradiances, while total leaf areas and unit leaf areas were lowest in full sunlight (Fig. 2). The LAR was higher at the lowest intensity irradiances. Similar to the stem dimensions, the stem dry mass (SDM) and root dry mass (RDM) were highest in partial shading (Fig. 3). Both

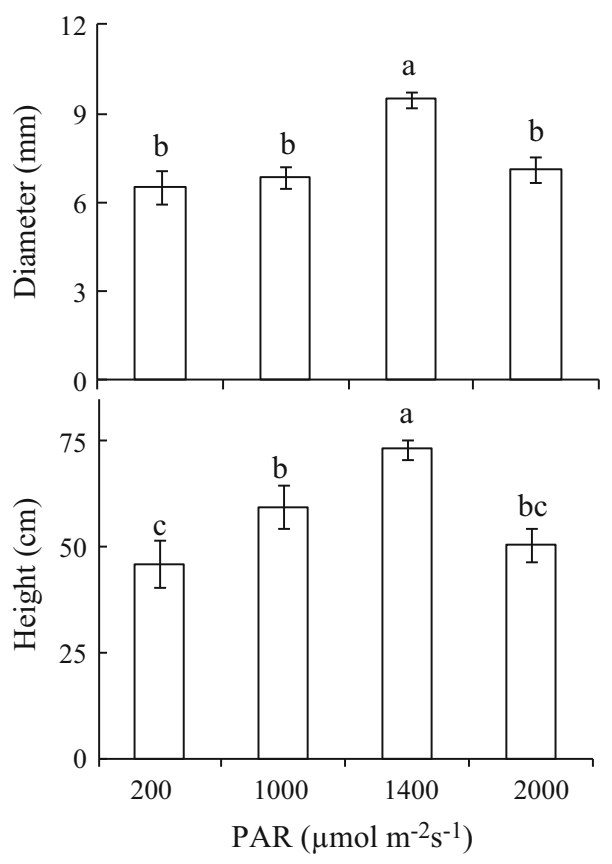

Fig. 1 Diameter and height of Cariniana estrellensis plants submitted to 200,1000, 1400, and $2000 \mu \mathrm{mol} \mathrm{m} \mathrm{m}^{-2} \mathrm{~s}^{-1}$ PAR for 104 days. The vertical bars represent the standard deviation of the mean $(\mathrm{n}=8)$. Different letters denote significant differences at level $P<0.05$, according to Tukey test 
Fig. 2 Leaves number, total leaf area, unit leaf area, leaf area ratio (LAR), specific leaf mass (SLM) of Cariniana estrellensis plants submitted to 200,1000 , 1400 , and $2000 \mu \mathrm{mol} \mathrm{m}^{-2} \mathrm{~s}^{-1}$ PAR for 104 days. The vertical bars represent the standard deviation of the mean $(n=8)$. Different letters denote significant differences at level $P<0.05$, according to Tukey test

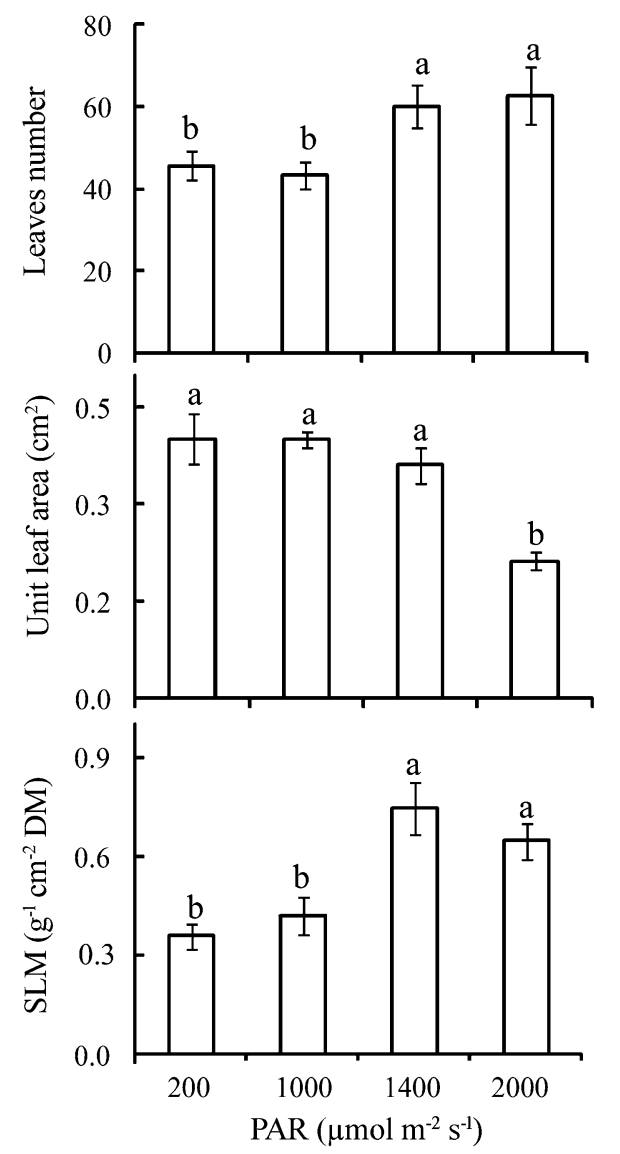

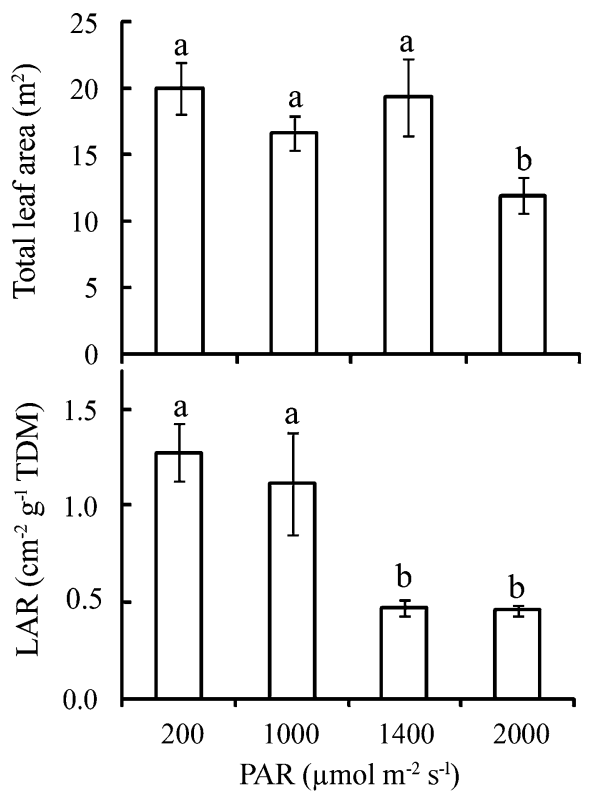

showed similar values in full sun and in the highest shading. The R:S ratio showed a tendency to increase with the intensity of irradiance. This was associated with an increasing root biomass allocation (RMR, root mass ratio) and decreasing leaf biomass allocation (LMR, leaf mass ratio) in response to increasing intensity of irradiance, especially in the highest irradiances (Fig. 4). Similar to the RMR, the allocation of stem biomass (SMR, stem mass ratio) was higher under partial shading and in full sunlight. The same tendency of stem dimensions in response to increasing irradiance was also observed for the NAR and RGR, with the highest values in partial shading (Fig. 5). NAR and RGR were different from the stem dimensions and lowest in deep shade in relation to full sunlight.

\section{Photosynthetic pigments}

The concentrations of $\mathrm{Chl} a, \mathrm{Chl} b$ and total Chl were highest under 200, 1000 and $1400 \mu \mathrm{mol} \mathrm{m}{ }^{-2} \mathrm{~s}^{-1}$ PAR and without differences between these treatments (Fig. 6). Full sunlight inhibited the concentration of these pigments which were $150 \%$ higher in relation to full sunlight. However, the Chl $a$ : $b$ ratio was higher in full sunlight and the concentration of carotenoids at the higher irradiance. These results were reflected in the $\mathrm{Chl}_{\text {Total }}$ : Carot ratios which showed higher values with the 200 and $1000 \mu \mathrm{mol} \mathrm{m} \mathrm{s}^{-1}$ PAR.

\section{Gas exchange}

The values of $A, g s, C i$, and $E$ were higher in partial shading and lowest in full sunlight (Fig. 7). The intermediate values were found with the densest shading. The values of $A, C i, g s$ and $E$ in partial shading were more than $170 \%$ higher in relation to most treatments. The value of $E$ in full sunlight was higher than under higher shading. The $A / E$ showed a tendency to decrease with the increase of irradiance intensity, with lowest value in full sunlight.

\section{Chl $\boldsymbol{a}$ fluorescence}

Low energy dissipation per active reaction centre $\left(\mathrm{DI}_{0} / \mathrm{RC}\right)$ was observed with $1400 \mu \mathrm{mol} \mathrm{m} \mathrm{m}^{-2} \mathrm{~s}^{-1}$ PAR as well as low density of the reaction centre (RC/ABS), better efficiency of electron transport between the reduced plastoquinone and the PSI final electron acceptors $\left(\mathrm{RE}_{0} / \mathrm{ET}_{0}\right)$, and higher performance index ( $\mathrm{PI}_{\mathrm{TOTAL}}$ ) (Fig. 8). The poorest performances of these parameters occurred in full sunlight and greater shading. $\mathrm{RC} / \mathrm{ABS}, \mathrm{ET}_{0} / \mathrm{ABS}$, and $\mathrm{TR}_{0} / \mathrm{ABS}$ were lowest in full sunlight, whereas $\mathrm{DI}_{0} / \mathrm{RC}$ was higher, 


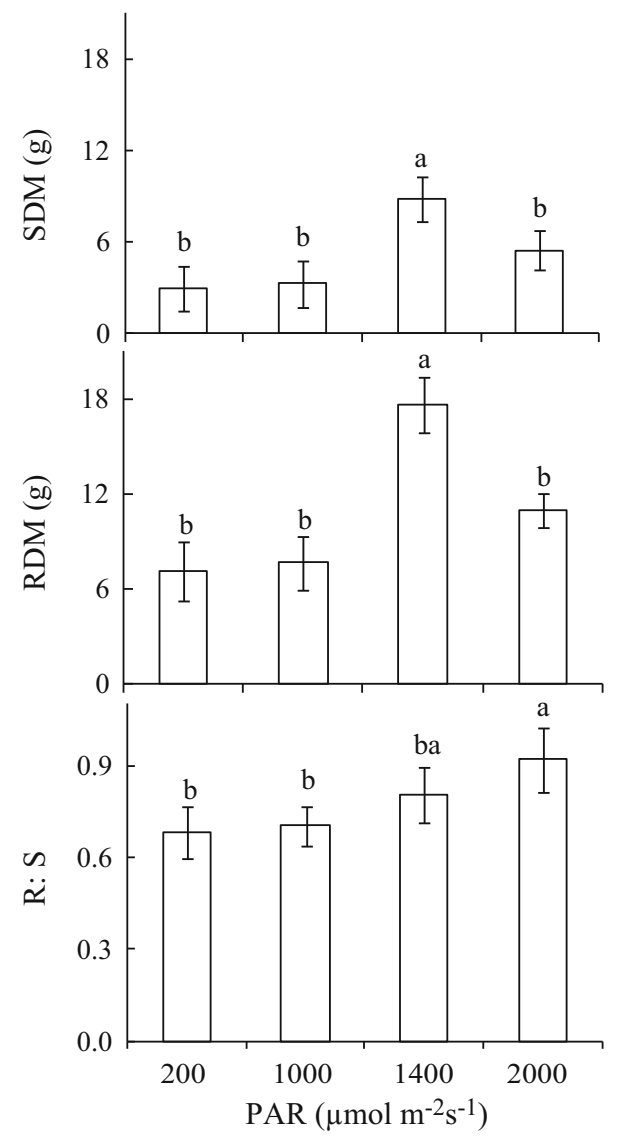

Fig. 3 Dry mass of the shoot (SDM), root (RDM) and R:S (root:shoot ratio) of Cariniana estrellensis plants submitted to 200, 1000, 1400, and $2000 \mu \mathrm{mol} \mathrm{m} \mathrm{m}^{-2} \mathrm{~s}^{-1}$ PAR. The vertical bars represent the standard deviation of the mean $(\mathrm{n}=8)$. Different letters denote significant differences at level $P<0.05$, according to Tukey test

resulting in a lower performance index $\left(\mathrm{PI}_{\mathrm{ABS}}\right)$ in full sunlight and lower total performance index $\left(\mathrm{PI}_{\mathrm{TOTAL}}\right)$ under partial shade and full sunlight. The efficiency of electron transport between the reduced $\mathrm{Q}_{\mathrm{A}}$ and the final electron acceptors of PSI $\left(\mathrm{RE}_{0} / \mathrm{ET}_{0}\right)$ was lower at higher shading levels and higher in full sunlight. However, the quantum yield of the electron transport from $\mathrm{Q}_{\mathrm{A}}^{-}$to the end electron acceptors of PSI $\left(\mathrm{RE}_{0} / \mathrm{ABS}\right)$ showed higher values with partial shading.

\section{Soluble carbohydrates}

The highest total soluble carbohydrates (TSC), fructose, and sucrose concentrations in the leaves were at higher irradiance intensities (Fig. 9). The lowest TSC concentrations were observed in deep shade. Glucose concentrations were similar between the treatments. The proportions of the carbohydrate concentrations followed as sucrose $>$ fructose $>$ glucose in all treatments.
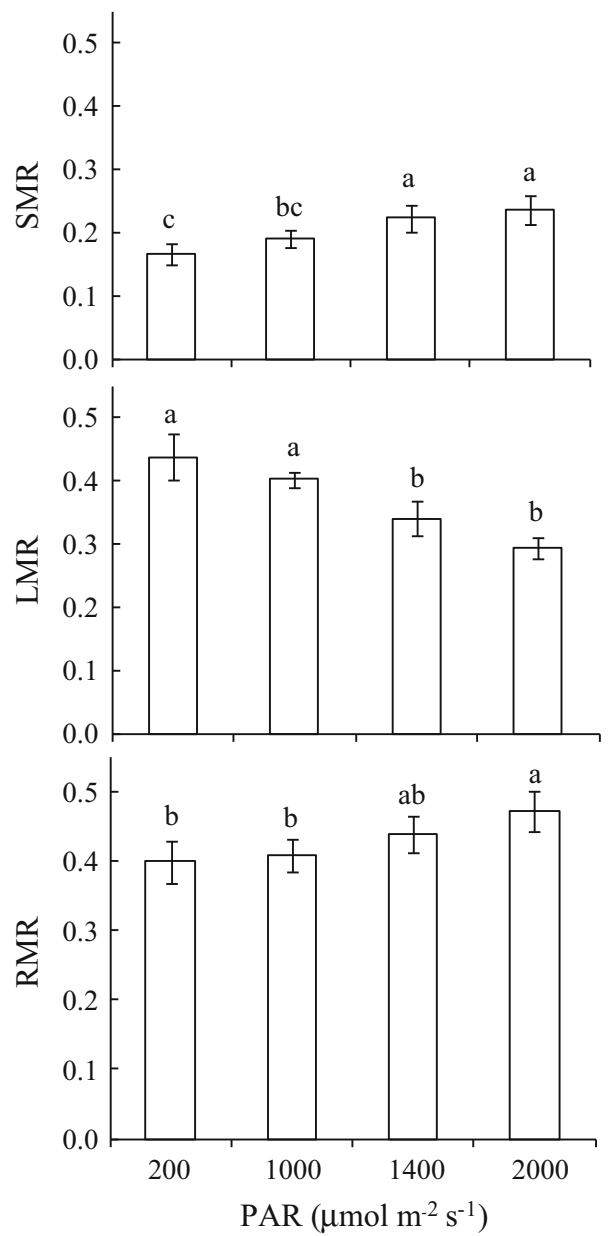

Fig. 4 SMR (stem mass ratio), LMR (leaf mass ratio), and RMR (root mass ratio) in Cariniana estrellensis plants submitted to 200, 1000, 1400 , and $2000 \mu \mathrm{mol} \mathrm{m}^{-2} \mathrm{~s}^{-1}$ PAR. The vertical bars represent the standard deviation of the mean $(n=8)$. Different letters denote significant differences at level $P<0.05$, according to Tukey test

\section{Leaf and stem anatomy}

The thickness of the abaxial epidermis, palisade and spongy parenchyma, leaf blades, and stomata density were found at the highest irradiance intensities, especially in full sunlight (Table 1). The values of theses anatomical variables did not differ between the lower irradiance intensities. The treatments had no effect on the relation between the palisade parenchyma and the spongy parenchyma. The xylem and secondary phloem thickness and cambium were higher under $1400 \mu \mathrm{mol} \mathrm{m} \mathrm{m}^{-2} \mathrm{~s}^{-1}$ PAR and without differences between the others treatments (Table 2 and Fig. 10). The periderm thickness was higher in partial shading and full sunlight without differences between the lower irradiance intensities. Vessel diameters and length was higher in partial shading and full sunlight, respectively, and without differences between the other treatments (Table 3 and Fig. 10). Higher vessel densities were 


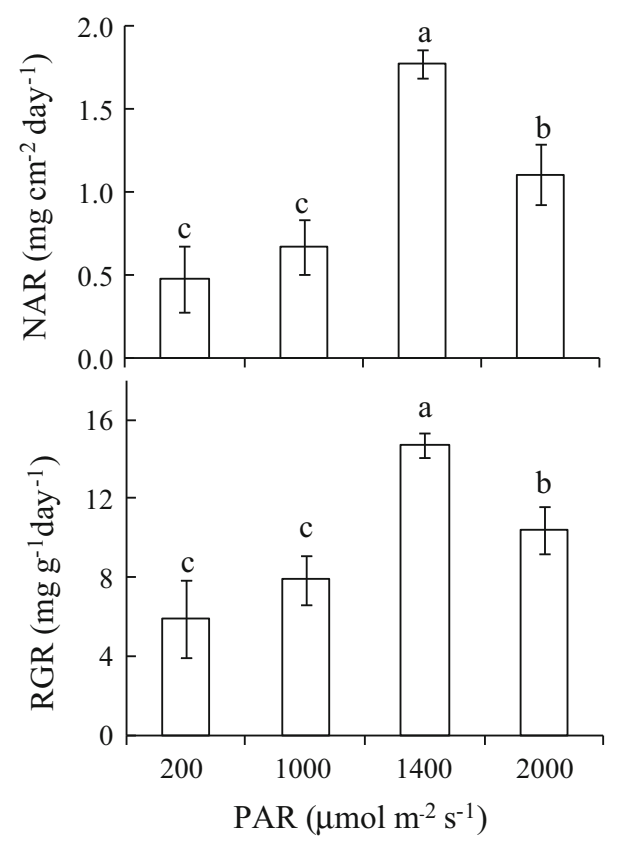

Fig. 5 Net assimilation rate (NAR) and relative growth rate (RGR) of Cariniana estrellensis plants submitted to 200,1000, 1400, and $2000 \mu \mathrm{mol} \mathrm{m}{ }^{-2} \mathrm{~s}^{-1}$ PAR. The vertical bars represent the standard deviation of the mean $(n=8)$. Different letters denote significant differences at level $P<0.05$, according to Tukey test found in the lowest irradiance intensities and in full sunlight.

\section{Phenotypic plasticity analysis}

Growth, biochemical, and photosynthesis variables presented different phenotypic PIs (Table 4). The growth component with the highest PI was the dry mass, which was reflected in the RGR (PI = 0.61). The lowest PI values were observed for the anatomical components, especially the thickness of the abaxial epidermis, vessel element diameters, and carbohydrates. The photosynthetic variables showed higher plasticity in response to the irradiance gradient, with gs being the highest PI (0.73). Considering the four groups of variables, the photosynthetic variables had the highest plasticity, followed by those of growth, biochemistry, and anatomy (Table 4).

\section{Discussion}

Contrary to the pre-established concept that shade or climax plants do not tolerate high irradiance (Swaine and Whitmore 1988), C. estrellensis survived and grew under
Fig. 6 Photosynthetic pigment concentrations of chlorophyll $a(\mathrm{Chl} a)$, chlorophyll $b(\mathrm{Chl} b)$, total chlorophyll $\left(\mathrm{Chl}_{\mathrm{Total}}\right)$, carotenoids (Carot), Chl $a: b$ and Total $\mathrm{Chl}_{\text {Total }}$ :Carot ratios in Cariniana estrellensis plants submitted to 200, 1000, 1400, and $2000 \mu \mathrm{mol} \mathrm{m}{ }^{-2} \mathrm{~s}^{-1}$ PAR. The vertical bars represent the standard deviation of the mean $(n=6)$. Different letters denote significant differences at level $P<0.05$, according to Tukey test
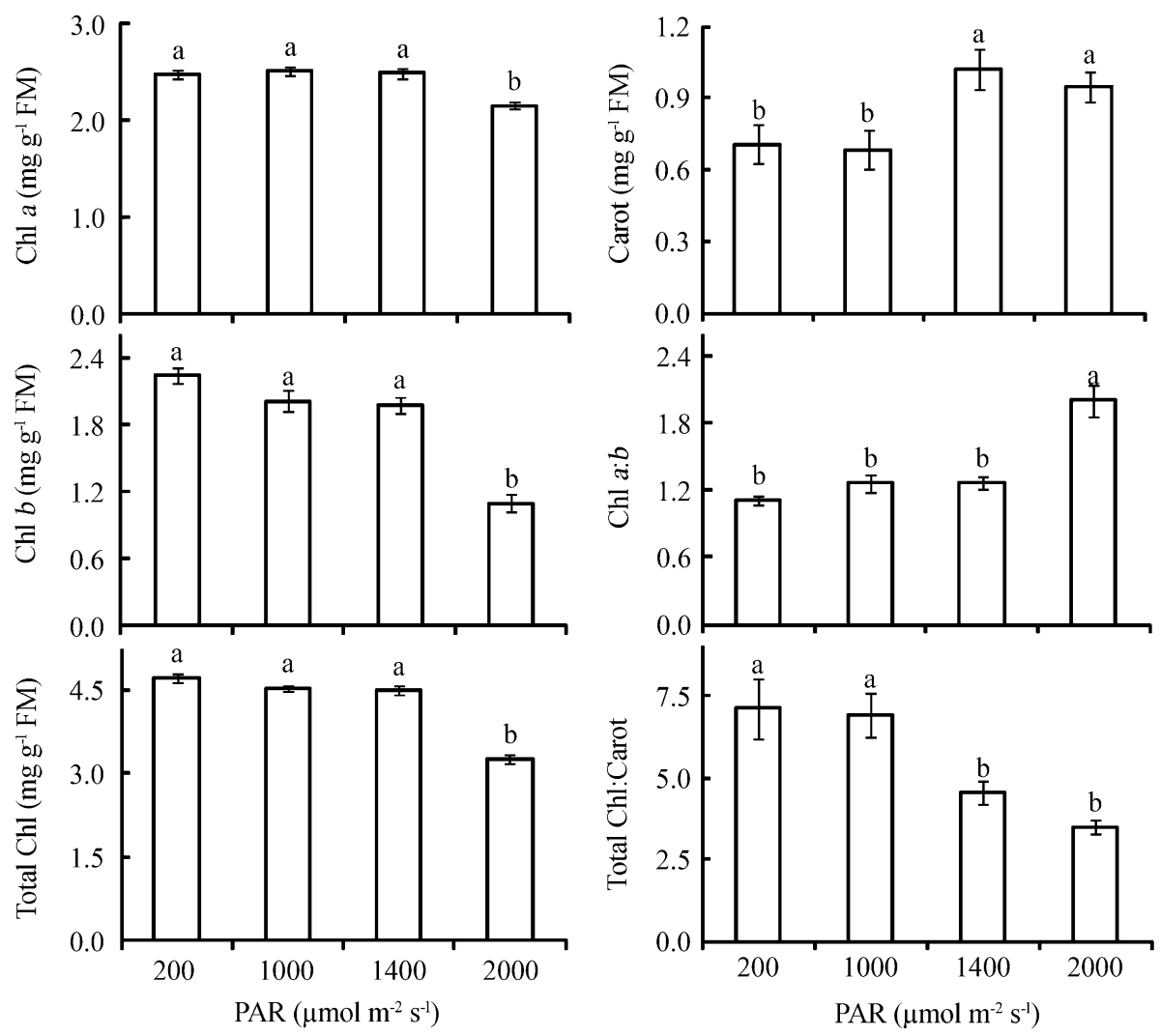
Fig. 7 Carbon photosynthetic assimilation $(A$, umol $\left.\mathrm{CO}_{2} \mathrm{~m}^{-2} \mathrm{~s}^{-1}\right)$, stomatal conductance ( $g s$, mol $\mathrm{H}_{2} \mathrm{O} \mathrm{m}^{-2} \mathrm{~s}^{-1}$ ), transpiration (E, mmol $\left.\mathrm{H}_{2} \mathrm{O} \mathrm{m}{ }^{-2} \mathrm{~s}^{-1}\right)$, water use efficiency $(A / E, \mu \mathrm{mol}$ $\mathrm{CO}_{2} \mathrm{mmol}^{-1} \mathrm{H}_{2} \mathrm{O}$ ), carboxylation efficiency ( $\mathrm{A} / \mathrm{Ci}$, mol air $\left.\cdot \mathrm{m}^{-2} \mathrm{~s}^{-1}\right)$ and, intrinsic water use efficiency $(\mathrm{A} / \mathrm{gs}, \mu \mathrm{mol}$ $\mathrm{CO}_{2} \cdot \mathrm{mol} \mathrm{H}_{2} \mathrm{O}^{-1}$ ) of Cariniana estrellensis plants submitted to 200, 1000, 1400, and $2000 \mu \mathrm{mol} \mathrm{m}{ }^{-2} \mathrm{~s}^{-1}$ PAR. The vertical bars represent the standard deviation of the mean $(n=6)$. Different letters denote significant differences at level $P<0.05$, according to Tukey test

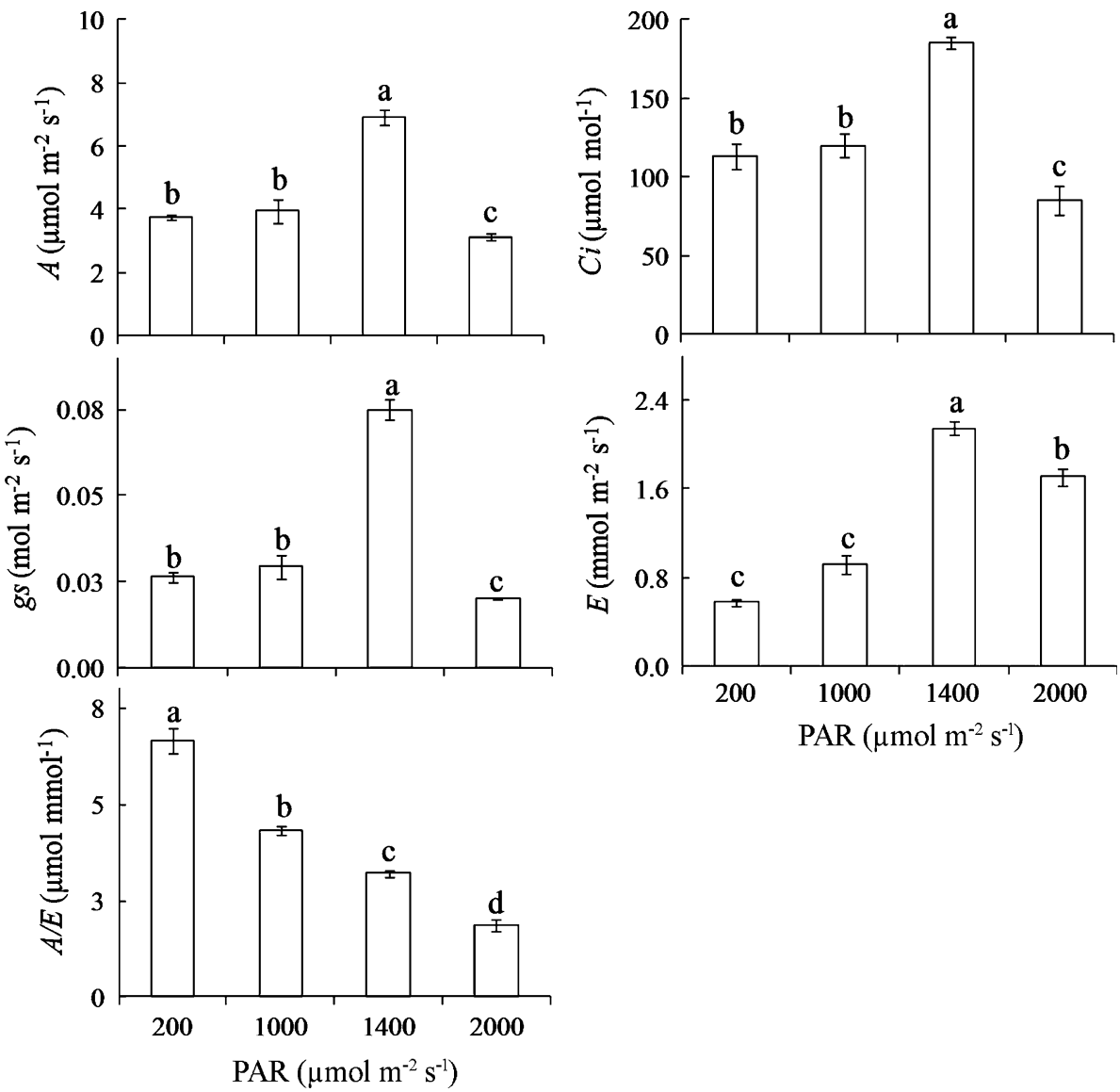

full sunlight. Similar behaviour was observed by Souza and Válio (2003) in certain late (climax or shade) and early (pioneer or sun) species from a Brazilian semi-deciduous tropical forest. Because a large portion of the growth variables of $C$. estrellensis were higher at $1400 \mu \mathrm{mol} \mathrm{m} \mathrm{s}^{-2}$ PAR (partial shading) is consistent with previous observations that climax species from the Brazilian Atlantic Forest grew better under partial shading (Frigeri 2007; Mengarda et al. 2009).

Although the higher number of leaves and SMR of $C$. estrellensis under the highest irradiance intensities is a characteristic of pioneer plants (Lambers et al. 2008), it appears that growth measures do not relate to the functional classes due to the absence of patterns between pioneer and climax tropical species under contrasting irradiance (Souza and Válio 2003).

On one hand, stem measurements, leaf numbers, biomass and growth rates (NAR and RGR) were higher with $1400 \mu \mathrm{mol} \mathrm{m} \mathrm{m}^{-2} \mathrm{~s}^{-1} \mathrm{PAR}$, suggesting that $C$. estrellensis prefers partial shade; on the other hand, LMR, leaf areas, and LAR were higher in low irradiance intensities, showing that theses morphological adjustments are typical of shade species when exposed to intense irradiance (Poorter and Nagel 2000; Lambers et al. 2008; Mengarda et al. 2009). Another characteristic that confirms this is based on the higher $\mathrm{R}: \mathrm{S}$ ratios and RMR in higher irradiance intensities. Under conditions of higher irradiance, shade plants tend to invest more in root growth in detriment of shoot growth in order to absorb more water and nutrients in this stressful condition (Lambers et al. 2008).

The higher SLM of $C$. estrellensis plants in partial shade and full sunlight can be interpreted as a strategy to avoid photo-oxidative damage by increasing the resistance to penetration of damaging intensive irradiance (Rossato and Kolb 2012). The lowest Chl $a$ and Chl $b$ concentrations in full sunlight are typical for a sun-acclimated condition observed in other non-pioneer tropical tree species (Gonçalves et al. 2001, 2005). The decrease in Chl $a$ and Chl $b$ and lowest of the total $\mathrm{Chl}_{\text {Total }}$ : Carot observed in $C$. estrellensis in full sunlight has also been observed in other tropical species (Gonçalves et al. 2005; Silvestrini et al. 2007; Mengarda et al. 2012), suggesting a decrease in energy assimilation of the antenna system (Laisk et al. 2005) and protection of photosystems from photo-oxidative damage under high irradiance levels (Marenco et al. 2001). Photo-protection was less related to the $\mathrm{Chl} a: b$ ratio which can either increase (Kitajima and Hogan 2003), decrease (Mengarda et al. 2012), or remain unchanged (Gonçalves et al. 2005; Silvestrini et al. 2007) in some tropical species under full sunlight. 


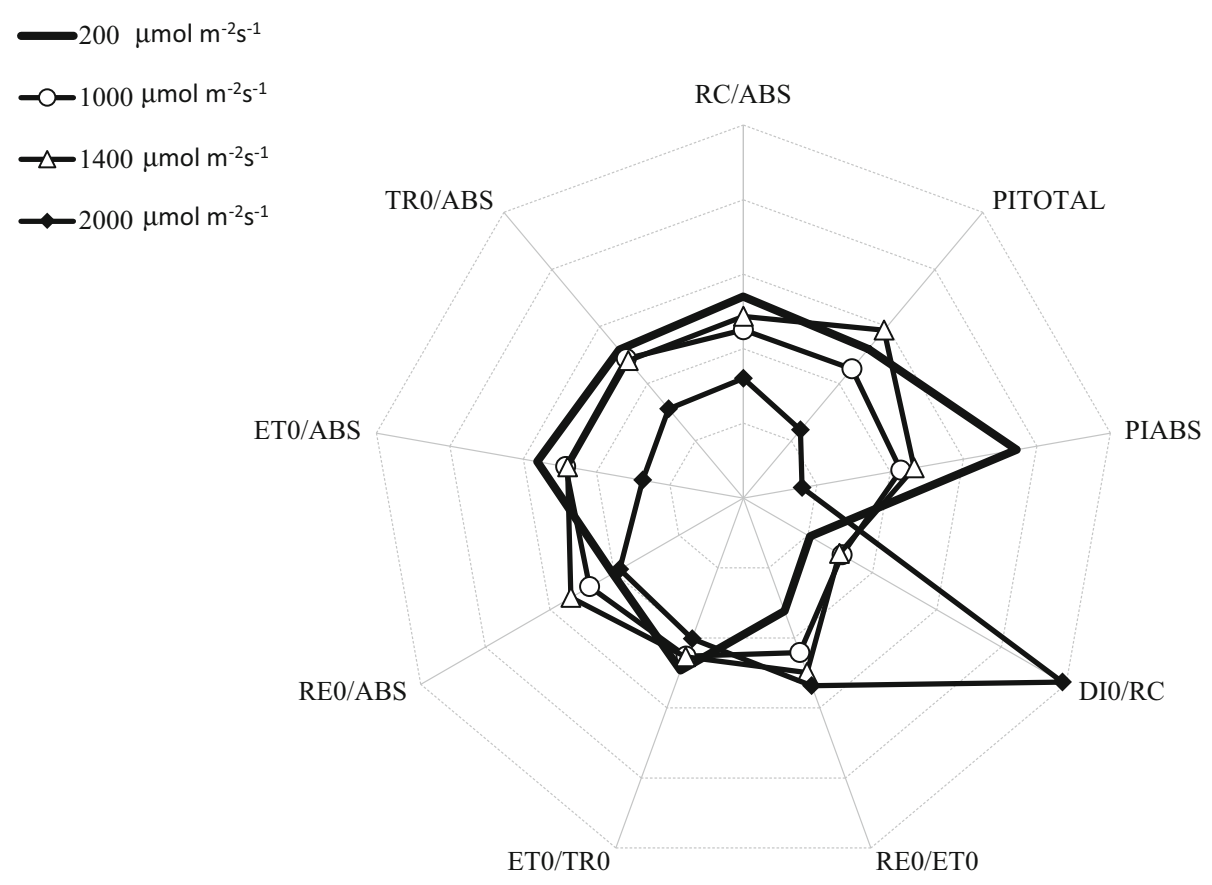

Fig. 8 Emission parameters of the chlorophyll fluorescence in Cariniana estrellensis plants submitted to 200 (solid line), 1000 (circle), 1400 (diamond), and 2000 (triangle) $\mu \mathrm{mol} \mathrm{m}^{-2} \mathrm{~s}^{-1}$ PAR. Density of the reaction centre (RC/ABS), total performance index $\left(\mathrm{PI}_{\text {TOTAL }}\right)$, performance index $\left(\mathrm{PI}_{\mathrm{ABS}}\right)$, energy dissipation per active reaction centre $\left(\mathrm{DI}_{\mathrm{O}} / \mathrm{RC}\right)$, efficiency of the electron transport between the reduced $\mathrm{Q}_{\mathrm{A}}^{-}$and the final electron acceptors of PSI $\left(\mathrm{RE}_{\mathrm{o}} / \mathrm{ET}_{\mathrm{o}}\right)$,

The highest chlorophyll content and lower Chl $a: b$ ratio under shading compared to full sun indicates a higher proportion of complex light energy collectors in an effort to optimize photochemical efficiencies found in Amazon rainforest species (Marenco et al. 2001). The high Chl $a: b$ ratio in full sun was related to low light absorption of photosystems in an effort to reduce stress caused by high radiation (Krause et al. 2001). The highest Carot levels under 1400 and $2000 \mu \mathrm{mol} \mathrm{m} \mathrm{m}^{-2} \mathrm{~s}^{-1}$ PAR compared with lower irradiance, confirms the participation of Carot in photo-protection of the photosynthetic apparatus (Laisk et al. 2005). This high level of Carot also could protect the PSII of the high sunlight incidence through the canopy (Barros et al. 2012) as observed on C. estrellensis plants in partial shade and full sun. These results suggest the ecological importance of these accessory pigments in the modulation of light absorption and energy dissipation (Barros et al. 2012).

These adjustments of pigment concentrations were reflected in the dissipation of excess light energy as heat (Li et al. 2007), which was confirmed by the high $\mathrm{DI}_{0} / \mathrm{RC}$, indicating partial inactivation of the PSII reaction centres (Yusuf et al. 2010). Although high irradiance increased $\mathrm{DI}_{0} / \mathrm{RC}$, decreased $\mathrm{TR}_{0} / \mathrm{ABS}$ and $\mathrm{ET}_{0} / \mathrm{ABS}$, and inhibited PSII (Xiang et al. 2013), consequent to the oxidative effect efficiency of the electron transport between the reduced plastoquinone and the PSI final electron acceptors $\left(\mathrm{ET}_{\mathrm{o}} / \mathrm{TR}_{\mathrm{o}}\right)$, quantum yield of the electron transport from $\mathrm{Q}_{\mathrm{A}}^{-}$to the end electron acceptors of PSI (REo/ ABS) and maximum quantum efficiency of photosystem II (PSII) $\left(\mathrm{ET}_{\mathrm{o}} / \mathrm{ABS}\right)$, maximum quantum yield of primary photochemistry $\left(\mathrm{TR}_{\mathrm{o}} / \mathrm{ABS}\right)$

of reactive oxygen species (Sielewiesiuk 2002), photodamage in C. estrellensis was avoided in higher irradiances due to the antioxidant action of fructose and sucrose (Mengarda et al. 2012). Soluble carbohydrates of low molecular weight act not only as osmoprotectants and stabilizers of cellular membranes but also as scavengers of ROS, and they play a novel role in the protection of photosynthesis from oxidative damage caused by environmental stress (Nishizawa et al. 2008). The majority of the Chl $a$ fluorescence parameters in C. estrellensis showed better photochemical reactions of plants in partial shade by presenting low energy dissipation per active reaction centre $\left(\mathrm{DI}_{0} / \mathrm{RC}\right)$, low density of the reaction centre (RC/ABS), and higher performance indices $\left(\mathrm{PI}_{\mathrm{ABS}}\right.$ and $\left.\mathrm{PI}_{\mathrm{TOTAL}}\right)$ under $1400 \mu \mathrm{mol} \mathrm{m} \mathrm{m}^{-2} \mathrm{~s}^{-1}$ PAR. This information may be confirmed by analysing the higher quantum yield of electron transport from $\mathrm{Q}_{\mathrm{A}}$ to $\mathrm{FSI}\left(\mathrm{RE}_{0} / \mathrm{ABS}\right)$, and $\mathrm{PI}_{\mathrm{TOTAL}}$ in $1400 \mu \mathrm{mol} \mathrm{m} \mathrm{m}^{-2} \mathrm{~s}^{-1}$ PAR difference of two climax species from the Amazon that showed higher performance indices in deep shade at $100 \mu \mathrm{mol} \mathrm{m}{ }^{-2} \mathrm{~s}^{-1}$ PAR when compared to full sunlight (Gonçalves et al. 2007).

The characteristics of $\mathrm{Chl} a$ fluorescence were reflected in photosynthetic variables. The greater efficiency of gas exchange under $1400 \mu \mathrm{mol} \mathrm{m} \mathrm{m}^{-2} \mathrm{~s}^{-1}$ may be attributed to higher stomatal opening providing higher influx of $\mathrm{CO}_{2}$ 

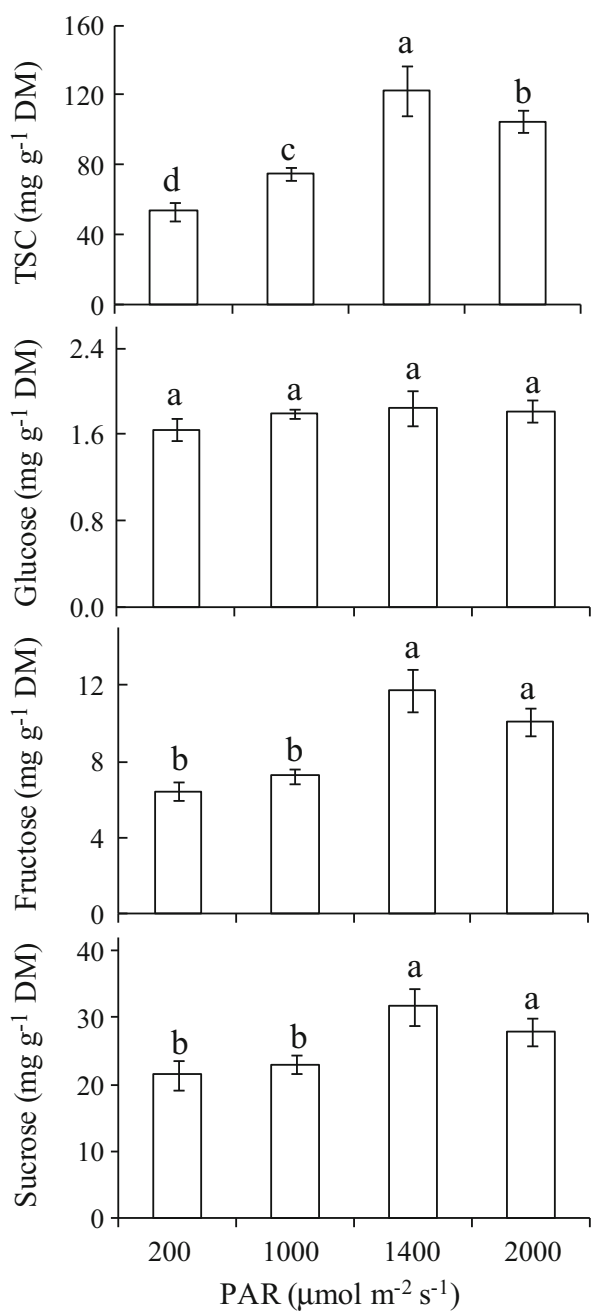

Fig. 9 Total soluble carbohydrate concentrations (TSC), glucose, fructose, and sucrose, in the leaf of Cariniana estrellensis plants submitted to $200,1000,1400$, and $2000 \mu \mathrm{mol} \mathrm{m}{ }^{-2} \mathrm{~s}^{-1}$ PAR. The vertical bars represent the standard deviation of the mean $(n=6)$. Different letters denote significant differences at level $P<0.05$, according to Tukey test and therefore higher rates of photosynthesis. The greatest water loss was through evapotranspiration $(E)$ in highest irradiance and reflected in lower water use efficiency $(A / E)$, confirming the low capacity of non-pioneer species to tolerate increased irradiance where water availability is lower compared to the inside forest (Siegert and Levia 2011). The reduction of $A / E$ of $C$. estrellensis with increased of irradiance confirms the sensitivity of climax species to increasing light intensity. As a climax species, higher gas exchange rates in the most intense shades were expected. But low luminosity was unsatisfactory to express maximum photosynthetic capacity because of the lower $g s$ limiting carbon inflow and transpiration (Taiz and Zeiger 2013). Even presenting the lowest gas in full sun, the transpiration of $C$. estrellensis in this condition was higher compared to more intense shades. However, this was insufficient to increase the carbon inflow and net photosynthesis. This suggests inhibiting rubisco activity due to higher leaf temperatures associated with elevated irradiance (Law and Crafts-Brandner 1999), as observed with other tropical species when exposed to high luminosity (Dias and Marenco 2007; Magalhães et al. 2009) or to photo-damage of the lower chloroplastidics pigments concentration and higher dissipation of light energy $\left(\mathrm{DI}_{0} /\right.$ $\mathrm{RC})$. The photo-protection strategies of $C$. estrellensis under low and high light intensities suggest that it has high competitive capacity in the different forest environment, which could explain its ability to expand over areas of Atlantic Forest (Barros et al. 2012).

The higher photosynthesis variables $(A, g s, C i$ and $E)$ in partial shading indicates that $C$. estrellensis has photosynthetic characteristics of an intermediate in the initial phase of growth, although the physiological and morphological characteristics of the species of this functional class is unknown. However, the photosynthesis is not always correlated with the functional class because certain shade tolerant tropical species can have higher photosynthetic

Table 1 Anatomical quantitative data of leaves of Cariniana estrellensis submitted to 200, 1000, 1400, and $2000 \mu \mathrm{mol} \mathrm{m} \mathrm{s}^{-2} \mathrm{PAR}^{-1}$ for 104 days

\begin{tabular}{llllllll}
\hline $\begin{array}{l}\text { PAR } \\
\left(\mu \mathrm{mol} \mathrm{m} \mathrm{m}^{-2} \mathrm{~s}^{-1}\right)\end{array}$ & \begin{tabular}{l} 
Thickness $(\mu \mathrm{m})$ \\
\cline { 2 - 6 }
\end{tabular} & $\begin{array}{l}\text { Adaxial } \\
\text { epidermis }\end{array}$ & $\begin{array}{l}\text { Palisade } \\
\text { parenchyma }\end{array}$ & $\begin{array}{l}\text { Spongy } \\
\text { parenchyma }\end{array}$ & $\begin{array}{l}\text { Abaxial } \\
\text { epidermis }\end{array}$ & $\begin{array}{l}\text { Leaf blade } \\
\text { PPP }\end{array}$ & $\begin{array}{l}\text { Stomatal } \\
\text { density } \\
\left(\mathrm{n}^{\circ} / \mathrm{mm}^{2}\right)\end{array}$ \\
\hline 200 & $6.7 \pm 0.16^{\mathrm{c}}$ & $32 \pm 0.74^{\mathrm{b}}$ & $46 \pm 1.08^{\mathrm{c}}$ & $5.5 \pm 0.14^{\mathrm{b}}$ & $90 \pm 1.2^{\mathrm{c}}$ & $1.4 \pm 0.2^{\mathrm{a}}$ & $98 \pm 6.6^{\mathrm{c}}$ \\
1000 & $6.2 \pm 0.23^{\mathrm{c}}$ & $34 \pm 0.54^{\mathrm{b}}$ & $42 \pm 0.08^{\mathrm{c}}$ & $5.0 \pm 0.11^{\mathrm{b}}$ & $95 \pm 1.0^{\mathrm{c}}$ & $1.2 \pm 0.2^{\mathrm{a}}$ & $110 \pm 7.6^{\mathrm{c}}$ \\
1400 & $7.5 \pm 0.28^{\mathrm{b}}$ & $48 \pm 0.56^{\mathrm{a}}$ & $59 \pm 1.12^{\mathrm{b}}$ & $6.4 \pm 0.21^{\mathrm{a}}$ & $129 \pm 1.9^{\mathrm{b}}$ & $1.2 \pm 0.5^{\mathrm{a}}$ & $138 \pm 8.3^{\mathrm{b}}$ \\
2000 & $8.7 \pm 0.21^{\mathrm{a}}$ & $52 \pm 0.88^{\mathrm{a}}$ & $68 \pm 1.48^{\mathrm{a}}$ & $6.2 \pm 0.18^{\mathrm{a}}$ & $135 \pm 1.5^{\mathrm{a}}$ & $1.3 \pm 0.3^{\mathrm{a}}$ & $152 \pm 7.6^{\mathrm{a}}$ \\
\hline
\end{tabular}

The mean values and standard error of the thickness of the adaxial and abaxial epidermis, palisade and spongy parenchyma, and leaf blade; the ratio between the thickness of the palisade and spongy parenchyma (PP/SP); and the stomatal density $\left(\right.$ stomata/mm $\left.{ }^{2}\right)(n=4)$ are presented. Different letters denote significant differences at level $P<0.05$, according to Tukey test 
Table 2 Anatomical qualitative data of the stems of Cariniana estrellensis submitted to 200 , 1000,1400 , and $2000 \mu \mathrm{mol} \mathrm{m} \mathrm{m}^{-2} \mathrm{~s}^{-1}$ PAR for 104 days

\begin{tabular}{lllll}
\hline PAR $\left(\mu \mathrm{mol} \mathrm{m} \mathrm{m}^{-2} \mathrm{~s}^{-1}\right)$ & \multicolumn{3}{l}{ Thickness $(\mu \mathrm{m})$} \\
\cline { 2 - 4 } & Secondary xylem & Cambial zone & Secondary phloem & Periderm \\
\hline 200 & $2382 \pm 70^{\mathrm{b}}$ & $31 \pm 1.1^{\mathrm{b}}$ & $414 \pm 17^{\mathrm{b}}$ & $36 \pm 1.3^{\mathrm{b}}$ \\
1000 & $2469 \pm 66^{\mathrm{b}}$ & $30 \pm 1.1^{\mathrm{b}}$ & $436 \pm 11^{\mathrm{b}}$ & $37 \pm 1.4^{\mathrm{b}}$ \\
1400 & $3793 \pm 115^{\mathrm{a}}$ & $50 \pm 1.5^{\mathrm{a}}$ & $674 \pm 22^{\mathrm{a}}$ & $69 \pm 1.4^{\mathrm{a}}$ \\
2000 & $2468 \pm 63^{\mathrm{b}}$ & $33 \pm 1.2^{\mathrm{b}}$ & $446 \pm 12^{\mathrm{b}}$ & $73 \pm 4.0^{\mathrm{a}}$ \\
\hline
\end{tabular}

Mean values and standard error of the thickness of the secondary xylem, cambial zone, secondary phloem, and periderm $(\mathrm{n}=4)$ are presented. Different letters denote significant differences at level $P<0.05$, according to Tukey test
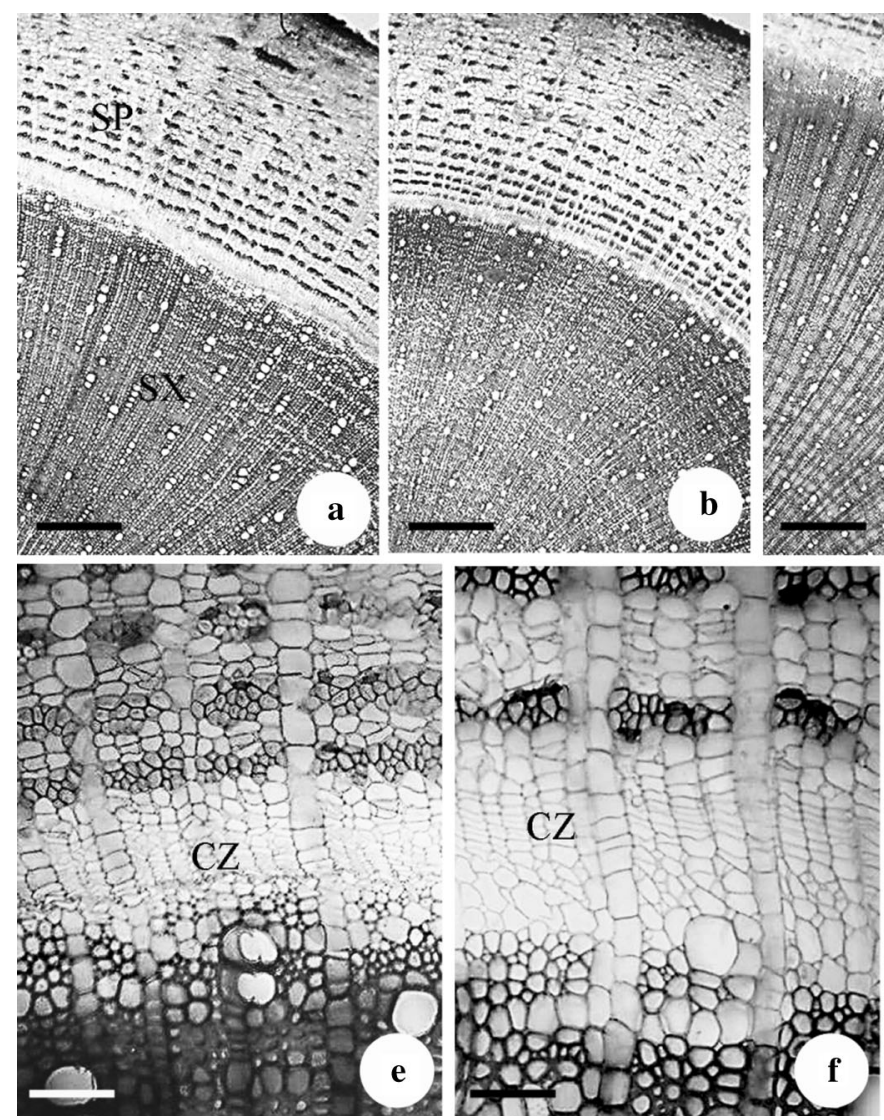
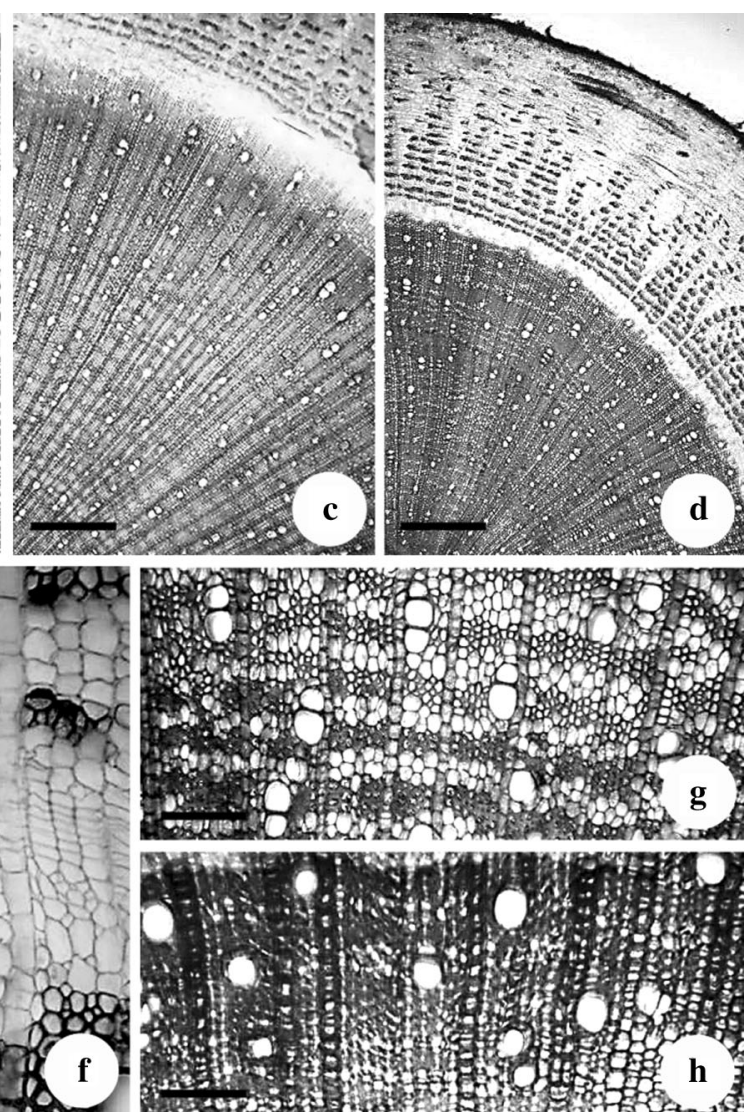

Fig. 10 Cross sections of a Cariniana estrellensis stem under different irradiance conditions. a, e and $\mathbf{g}-200 \mu \mathrm{mol} \mathrm{m} \mathrm{m}^{-2} \mathrm{~s}^{-1}$ PAR. b- $1000 \mu \mathrm{mol} \mathrm{m}^{-2} \mathrm{~s}^{-1}$ PAR. c, f and h-
$1400 \mu \mathrm{mol} \mathrm{m}{ }^{-2} \mathrm{~s}^{-1}$ PAR. d-2000 $\mu \mathrm{mol} \mathrm{m}^{-2} \mathrm{~s}^{-1}$ PAR. (CZ cambial zone, $S P$ secondary phloem, $S X$ secondary xylem). $\operatorname{Bar}=100 \mu \mathrm{m}(\mathbf{a}, \mathbf{b}, \mathbf{c}, \mathbf{d}) ; 20 \mu \mathrm{m}(\mathbf{e}, \mathbf{f}) ; 50 \mu \mathrm{m}(\mathbf{g}, \mathbf{h})$
Table 3 Anatomical quantitative data of the secondary xylem vessel elements in the stem of Cariniana estrellensis submitted to $200,1000,1400$, and $2000 \mu \mathrm{mol} \mathrm{m}{ }^{-2} \mathrm{~s}^{-1}$ PAR for 104 days

\begin{tabular}{llll}
\hline PAR $\left(\mu \mathrm{mol} \mathrm{m} \mathrm{m}^{-2} \mathrm{~s}^{-1}\right)$ & \multicolumn{2}{l}{ Vessel elements } \\
\cline { 2 - 4 } & Diameter $(\mu \mathrm{m})$ & Length $(\mu \mathrm{m})$ & Density $\left(\mathrm{n}^{\circ} \mathrm{mm}^{-2}\right)$ \\
\hline 200 & $44 \pm 1.1^{\mathrm{b}}$ & $377 \pm 13.0^{\mathrm{b}}$ & $36 \pm 4.3^{\mathrm{a}}$ \\
1000 & $44 \pm 1.5^{\mathrm{b}}$ & $375 \pm 11.0^{\mathrm{b}}$ & $38 \pm 1.4^{\mathrm{a}}$ \\
1400 & $51 \pm 1.7^{\mathrm{a}}$ & $383 \pm 12.6^{\mathrm{b}}$ & $28 \pm 1.9^{\mathrm{b}}$ \\
2000 & $46 \pm 1.5^{\mathrm{b}}$ & $409 \pm 12.6^{\mathrm{a}}$ & $36 \pm 2.1^{\mathrm{a}}$ \\
\hline
\end{tabular}

Mean values and standard error of the vessel diameter, length and density $\left(\mathrm{n}^{\circ} \mathrm{mm}^{-2}\right)(\mathrm{n}=4)$ are presented. Different letters denote significant differences at level $P<0.05$, according to Tukey test 
Table 4 Plasticity index [PI = (maximum $-\operatorname{minimum}) /$ maximum $]$ following the method of Valladares et al. 2000) of the morphological, biochemical, photosynthesis and gas exchange variables in Cariniana estrellensis submitted to 200,1000,1400, and $2000 \mu \mathrm{mol} \mathrm{m} \mathrm{m}^{-2} \mathrm{~s}^{-1}$ PAR for 104 days

\begin{tabular}{|c|c|c|}
\hline Type of variable & Variable & PI \\
\hline Growth & Height & 0.37 \\
\hline Growth & Diameter & 0.4 \\
\hline Growth & Specific leaf area (SLA) & 0.38 \\
\hline Growth & Total dry mass & 0.54 \\
\hline Growth & Leaf area ratio (LAR) & 0.58 \\
\hline Growth & Root: shoot ratio (R:S) & 0.36 \\
\hline Growth & Relative growth rate (RGR) & 0.61 \\
\hline Photosynthesis & Net assimilation rate (NAR) & 0.65 \\
\hline Photosynthesis & Total chlorophyll concentration & 0.49 \\
\hline Photosynthesis & Carotenoids concentration & 0.33 \\
\hline Photosynthesis & Photosynthetic rate $(A)$ & 0.54 \\
\hline Photosynthesis & Transpiration $(E)$ & 0.65 \\
\hline Photosynthesis & Stomatal conductance $(g s)$ & 0.73 \\
\hline Photosynthesis & Internal carbon concentration $(\mathrm{Ci})$ & 0.65 \\
\hline Photosynthesis & Water use efficiency $(A / E)$ & 0.71 \\
\hline Biochemical & Foliar glucose & 0.11 \\
\hline Biochemical & Foliar fructose & 0.45 \\
\hline Biochemical & Foliar sucrose & 0.32 \\
\hline Anatomical & Adaxial epidermis & 0.23 \\
\hline Anatomical & Palisade parenchyma & 0.39 \\
\hline Anatomical & Spongy parenchyma & 0.32 \\
\hline Anatomical & Abaxial epidermis & 0.11 \\
\hline Anatomical & Total blade thickness & 0.33 \\
\hline Anatomical & Stomatal density & 0.35 \\
\hline Anatomical & Secondary xylem & 0.37 \\
\hline Anatomical & Cambial zone & 0.29 \\
\hline Anatomical & Secondary phloem & 0.39 \\
\hline Anatomical & Periderm & 0.5 \\
\hline Anatomical & Vessel element diameter & 0.14 \\
\hline Anatomical & Vessel element density & 0.28 \\
\hline
\end{tabular}

All the analysed variables showed significant differences because of luminosity variations

activity under full sunlight (Marenco et al. 2001) or lower activity under full sunlight (Gonçalves et al. 2005; Silvestrini et al. 2007; Mengarda et al. 2009). This is similar to that observed with $C$. estrellensis in this study. Nevertheless, gas exchange measurements show that this species had the best performance under partial shading.

Another factor that may have contributed to the better photochemical performance of $C$. estrellensis under $1400 \mu \mathrm{mol} \mathrm{m}^{-2} \mathrm{~s}^{-1}$ PAR was the remarkable elongation of the palisade and spongy parenchyma at the highest irradiance intensities. Elongation of the parenchyma cells may increase the resistance to penetration of damaging intensive irradiance, thus minimizing photodamage effects
(Rossato and Kolb 2012). This increased elongation of parenchyma cells has been attributed to higher soluble carbohydrate concentrations that act as osmoregulators, decreasing the cell water potential and promoting water entrance into the cells (Terashima et al. 2006; Mengarda et al. 2009). The greatest thickening of the epidermal cells in partial shade and full sun is another strategy to increase the resistance to water loss by transpiration (Taiz and Zeiger 2013).

Increased stomatal density in the major levels of irradiance may have favored the formation of the limitrophe layer, reducing the gradient concentration between the atmosphere and leaf surface (Taiz and Zeiger 2013). It may have increased the resistance to water loss by transpiration. However, plants in full sun with higher stomatal densities showed higher transpiration rates compared to plants at higher shading (200 and $1000 \mu \mathrm{mol} \mathrm{m} \mathrm{m}^{-2} \mathrm{~s}^{-1}$ PAR). This difference may be due to increased environmental temperatures of this treatment which caused major evapotranspiration flows in plants subjected to high irradiation and consequently, reduced leaf overheating (Marques et al. 2000). Moreover, studies have shown that environmental factors such as light can regulate the development of the stomata (Nadeau and Sack 2002).

Similar to the mesophyll, C. estrellensis stem cells were also affected by irradiance. The greater thickening of the secondary xylem and periderm under partial shading indicates, respectively, higher water conductance (Schuetz et al. 2013) and the protection of internal stem structures against heat (Ginzberg et al. 2009). The thicker secondary phloem indicates greater photo assimilates transport capacity (Gaburro et al. 2014) from organ source to drain, confirmed by the higher concentration of glucose and fructose in the leaves.

Phenotypic plasticity of $C$. estrellensis may be interpreted as an adaptive response to the changes in light intensity inside the forest as suggested by Barros et al. (2012) for the climax species Dalbergia nigra (Vell.) Allemão ex Benth. of the Atlantic Forest. The higher plasticity of the gas exchange variables (photosynthesis) in relation to morphological variables (growth and anatomical) and biochemical confirms the ability of climax species of tropical forests to adjust to different light conditions (Valladares and Niinemets 2008; Gaburro et al. 2014). Thus, the climax species can belong to different vegetation types since understory to caponier as C. estrellensis (Swaine and Whitmore 1988; Rozendaal et al. 2006; Nunes and Petrere-Júnior 2012). The greater plasticity of physiological characteristics of climax species appears to account for survival in areas of low or high radiation (Valladares et al. 2000; Valladares and Niinemets 2008; Gaburro et al. 2014). Even being a climax species, $C$. estrellensis presents functional characteristics for 
reforestation in open areas. The species does this by economizing the water consumption indicated by the lower efficiency of water use $(A / E)$ in the full sun. Nevertheless, cultivation in partially shaded environments seems to be the ideal for the species. The higher efficiency of gas exchange, photochemical reaction and growth at $1400 \mu \mathrm{mol} \mathrm{m} \mathrm{m}^{-2} \mathrm{~s}^{-1}$ PAR suggests the planting of $C$. estrellensis with species that provide partial shading.

Open Access This article is distributed under the terms of the Creative Commons Attribution 4.0 International License (http://crea tivecommons.org/licenses/by/4.0/), which permits unrestricted use, distribution, and reproduction in any medium, provided you give appropriate credit to the original author(s) and the source, provide a link to the Creative Commons license, and indicate if changes were made.

\section{References}

Barros FV, Goulart MF, Telles SBS, Lovato MB, Valladares F, Lemos-Filho JP (2012) Phenotypic plasticity to light of two congeneric trees from contrasting habitats: brazilian Atlantic forest versus cerrado (savanna). Plant Biol 14:208-215

Budowski G (1965) Distribution of tropical American rain forest species in the light of successional processes. Turrialba 15:40-42

Bukatsch F (1972) Bemerkungen zur doppelfärbung astrablausafranin. Mikrokosmos 61:255

Dias DP, Marenco R (2007) Fotossíntese e fotoinibição em mogno e acariquara em função da luminosidade e temperatura foliar. Pesqui Agropecu Bras 42(3):305-311

Dubois M, Gilles KA, Hamilton JK, Rebers PA, Smith F (1956) Colorimetric method for determination of sugars and related substances. Anal Chem 28:350-356

Engel VL (2001) Estudo fenológico de espécies arbóreas de uma floresta tropical em Linhares, In: ES (Ph.D. Thesis). Universidade Estadual de Campinas, São Paulo

Franklin GL (1945) Preparation of thin sections of synthetic resins and wood-resin composites, and a new macerating method for wood. Nature 155:51

Frigeri RBC (2007) Relação entre raiz e parte aérea de plântulas de espécies arbóreas tropicais sob diferentes níveis de radiação solar (Ph.D. Thesis). Universidade Estadual de Campinas, São Paulo

Gaburro TA, Gama VN, Zanetti L, Milanez CRD, Cuzzuol GRF (2014) Physiological variables related to photosynthesis are more plastic than the morphological and biochemistry in nonpioneer tropical trees under contrasting irradiance. Braz $\mathrm{J}$ Bot 37(4):395-402

Ginzberg I, Barel G, Ophir R, Tzin E, Tanami Z, Muddarangappa T, De Jong W, Fogelman E (2009) Transcriptomic profiling of heatstress response in potato periderm. J Exp Bot 60(15):4411-4421

Gonçalves JFC, Marenco RA, Vieira G (2001) Concentration of photosynthetic pigments and chlorophyll fluorescence of mahogany and tonka bean under two light environments. Braz J Plant Physiol 13:149-157

Gonçalves JFC, Barreto DCS, Santos-Júnior UM, Fernandes AV, Sampaio PTB, Buckeridge MS (2005) Growth, photosynthesis and stress indicators in young rosewood plants (Aniba rosaeodora Ducke) under different light intensities. Braz J Plant Physiol 17:325-334

Gonçalves JFC, Santos-Júnior UM, Nina-Júnior AR, Chevreuil LR (2007) Energetic flux and performance index in copaiba
(Copaifera multijuga Hayne) and mahogany (Swietenia macrophylla King) seedlings grown under two irradiance environments. Braz J Plant Physiol 19:171-184

Hanba YT, Kogami H, Terashima I (2002) The effect of growth irradiance on leaf anatomy and photosynthesis in Acer species differing in light demand. Plant Cell Environ 25:1021-1030

Jermyn MA (1956) A new method for the determination of ketohexoses in presence of aldohexoses. Nature 177:38-39

Johansen DA (1940) Plant microtechnique. McGraw-Hill Book Co., New York

Kitajima K, Hogan KP (2003) Increases of chlorophyll $a / b$ ratios during acclimation of tropical woody seedlings to nitrogen limitation and high light. Plant Cell Environ 26:857-865

Kraus JE, Arduim M (1997) Manual básico de métodos em morfologia vegetal. Universidade Rural, Seropédica

Krause GH, Koroleva OY, Dalling JW, Winter K (2001) Acclimation of tropical tree seedlings to excessive light in simulated tree-fall gaps. Plant Cell Environ 24:1345-1352

Laisk A, Eichelmann H, Oja V, Rasulov B, Padu E, Bichele I, Pettai $\mathrm{H}, \mathrm{Kull} \mathrm{O}$ (2005) Adjustment of leaf photosynthesis to shade in a natural canopy: rate parameters. Plant Cell Environ 28:375-388

Lambers H, Poorter H (1992) Inherent variation in growth rate between higher plants: a search for physiological causes and ecological consequences. Adv Ecol Res 23:187-261

Lambers H, Chapim FS III, Pons TL (2008) Plant physiological ecology, 2nd edn. Springer, Berlin

Law RD, Crafts-Brandner SJ (1999) Inhibition and acclimation of photosynthesis to heat stress is closely correlated with activation of Ribulose-1,5-bisphosphate carboxylase/oxygenase. Plant Physiol 120:173-182

Li XG, Li JY, Zhao JP, Xu PL, He QW (2007) Xanthophyll cycle and inactivation of photosystem II reaction centers alleviating reducing pressure to photosystem I in morning glory leaves under short-term high irradiance. J Integr Plant Biol 49:1047-1053

Lichtenthaler HK, Welburn AR (1983) Determination of total carotenoids and chlorophylls $a$ and $b$ of leaf extracts in different solvents. Biochem Soc Trans 11:591-592

Magalhães NS, Marenco RA, Mendes KR (2009) Aclimatação de mudas de acariquara à alta irradiância. Pesqui Agropecu Bras 44(7):687-694

Marcati CR, Milanez CRD, Machado SR (2008) Seasonal development of secondary xylem and phloem in Schizolobium parahyba (Vell.) Blake (Leguminosae: caesalpinoidae). Trees 22:3-12

Marenco RA, Golçalves JFC, Vieira G (2001) Leaf gas exchange and carbohydrates in tropical trees different in successional status in two light environments in central Amazonia. Tree Physiol 21:1311-1318

Marques AR, Garcia QS, Rezende JLP, Fernandes GW (2000) Variations in leaf characteristics of two species of Miconia in the Brazilian cerrado under different light intensities. Trop Ecol 41:47-60

Mengarda LHG, Souza RLF, Campostrini E, Reis FO, Vendrame WA, Cuzzuol GRF (2009) Light as an indicator of ecological succession in brazilwood (Caesalpinia echinata Lam.). Braz J Plant Physiol 21:55-64

Mengarda LHG, Milanez CRD, Silva DM, Aguilar MAG, Cuzzuol GRF (2012) Morphological and physiological adjustments of brazilwood (Caesalpinia echinata Lam.) to direct solar radiation. Braz J Plant Physiol 24(3):161-172

Nadeau JA, Sack FD (2002) Stomatal development in Arabidopsis. In: Somerville CR, Meyerowitz EM (eds) The Arabidopsis Book. American Society of Plant Biologists, Rockville

Nishizawa A, Yabuta Y, Shigeoka S (2008) Galactinol and raffinose con-stitute a novel function to protect plants from oxidative damage. Plant Physiol 147:1251-1263 
Nunes YRF, Petrere-Júnior M (2012) Structure and dynamics of Cariniana estrellensis (Lecythidaceae) population in a fragment of Atlantic Forest in Minas Gerais, Brazil. Rodriguésia 63(2):257-267

Oguchi R, Hikosaka K, Hirose T (2005) Leaf anatomy as a constraint for photosynthetic acclimation: differential responses in leaf anatomy to increasing growth irradiance among three deciduous trees. Plant Cell Environ 28:916-927

Poorter H, Nagel O (2000) The role of biomass allocation in the growth response of plants to different levels of light, $\mathrm{CO}_{2}$, nutrients and water: a quantitative review. Aust J Plant Physiol 27:595-607

Riazi A, Matsuda K, Arslan A (1985) Water-stress induced changes in concentrations of proline and other solutes in growing regions of young barley leaves. J Exp Bot 36:1716-1725

Rossato DR, Kolb RM (2012) Gochnatia polymorpha (Less.) Cabrera (Asteraceae) changes in leaf structure due to differences in light and edaphic conditions. Acta Botanica Bras 24:133-149

Rozendaal DMA, Hurtado VH, Poorter L (2006) Plasticity in leaf traits of 38 tropical tree species in response to light: relationships with demand and adult stature. Funct Ecol 20:207-216

Sass JE (1958) Elements of botanical microtechnique. McGraw-Hill, New York

Schuetz M, Smith R, Ellis B (2013) Xylem tissue specification, patterning, and differentiation mechanisms. J Exp Bot 64(1):11-31

Siegert CM, Levia DF (2011) Stomatal conductance and transpiration of co-occurring seedlings with varying shade tolerance. Trees 25:1091-1102

Sielewiesiuk J (2002) Why there are photodamages to photosystem II at low light intensities. Acta Physiol Plant 24:399-406

Silvestrini M, Válio IFM, Mattos EA (2007) Photosynthesis and carbon gain under contrasting light levels in seedlings of a pioneer and a climax tree from a Brazilian semideciduous tropical forest. Braz J Bot 30:463-474

Souza RP, Válio IFM (2003) Seedling growth of fifteen Brazilian tropical tree species differing in sucessional status. Braz J Bot 26:35-47

Strasser RJ, Srivasta A, Tsimilli-Michael M (2004) Analysis of the fluorescence transient. In: Papageorgiou GC, Govindjee (eds)
Chlorophyll fluorescence: a signature of photosynthesis. Advances in Photosynthesis and Respiration Series, vol 19. pp 321-362

Strasser RJ, Tsimilli-Michael M, Qiang S, Goltsev V (2010) Simultaneous in vivo recording of prompt and delayed fluorescence and 820-nm reflection changes during drying and after rehydration of the resurrection plant Haberlea rhodopensis. Biochem Biophys Acta 1797:1313-1326

Swaine MD, Whitmore TC (1988) On the definition of ecological species groups in tropical rain forests. Vegetatio 75:81-86

Taiz L, Zeiger E (2013) Plant Physiology, 5th edn. Publishers Sunderland, Massachusetts

Terashima I, Hanba YT, Tazoe Y, Vyas P, Yano S (2006) Irradiance and phenotype: comparative eco-development of sun and shade leaves in relation to photosynthetic $\mathrm{CO}_{2}$ diffusion. $\mathrm{J}$ Exp Bot $57: 343-354$

Valladares F, Niinemets U (2008) Shade tolerance, a key plant feature of complex nature and consequences. Annu Rev Ecol Evol Syst 38:237-257

Valladares F, Wright SJ, Lasso E, Kitajima K, Pearcy RW (2000) Plastic phenotypic response to light of 16 congeneric shrubs from a Panamanian rainforest. Ecology 81:1925-1936

Valladares F, Arrieta S, Aranda I, Lorenzo D, Sanches-Gómez D, Tena D, Suárez F, Pardos PA (2005) Shade tolerance, photoinhibition sensitivity and phenotypic plasticity of Ilex aquifolium in continental Mediterranean sites. Tree Physiol 25:1041-1052

Vieira TO, Lage-Pinto F, Ribeiro DR, Alencar TS, Vitória AP (2011) Light stress in jequitibá-rosa seedlings (Cariniana legalis Lecythidaceae): monitoring photosynthetic acclimation capacity under two light intensities. Vértices 13(3):129-142

Xiang M, Chen S, Wang L, Dong Z, Huang J, Zhang Y, Strasser RJ (2013) Effect of vulculic acid produced by Nimbya alternantherae on the photosynthetic apparatus of Alternanthera philoxeroides. Plant Physiol Biochem 65:81-88

Yusuf MA, Kumar D, Rajwanshi R, Strasser RJ, Tsimilli-Michael M, Govindjee Sarin NB (2010) Overexpression of y-tocopherol methyl transferase gene in Brassica juncea plants alleviates abiotic stress: physiological and chlorophyll $a$ fluorescence measurements. Biochem Biophys Acta 1797:1428-1438 